$\triangle U T H O R$ 'S ABSTRACT OF THIS PAPER ISSUED

BX THE BIBLIOGRAPHIC SERVICE, JUNE 27

\title{
ON THE GROWTH OF THE LARGEST NERVE CELLS IN THE SUPERIOR CERVICAL SYMPATHETIC GAN- GLION OF THE ALBINO RAT-FROM BIRTH TO MATURITY
}

\author{
CHI PING \\ 'he Wistar Institute of Anatomy \\ SIX CHARTS AND ONE PLATE \\ INTRODUCTION
}

'I'his paper contains observations on the largest nerve cells in the superior cervical sympathetic ganglion of the albino rat. The purpose of this study is to trace the growth of these cells by their increase in diameter in relation to the age and size of the animal. In order to compare the possible differences in growth in the sympathetic nerve cells due to sex, a male and a female rat of each age were used throughout the series of observations.

The author desires to express his sincere appreciation and gratitude to Dr. M. J. Greenman for granting him the privileges and facilities of the Institute for this investigation, and to Dr. H. H. Donaldson, under whose direction the work was carried on and whose valuable advice and guidance enabled him to formulate his results.

\section{MATERIAL}

The material used for this investigation consisted of sixteen pairs of albino rats, of known ages, from 1 to 365 days. Besides these, two females of 540 days and 570 days, respectively, were used for comparison. All these were obtained from the animal colony at. The Wistar Institute and belonged to the so-called 'standard strain.' In selecting the specimens, five-day intervals were taken between each two ages from birth to thirty days, but from this age onward greater intervals were used. The body weight, body length, sex, and age of each rat were recorded. 
For comparison and control a second limited series of inbred albino rats was also used. The data for this series are given on page 303. Up to the introduction of this series the paper deals only with albino rats of the 'standard' strain.

\section{TECHNIQUE}

The rat was etherized and, after the necessary measurements had been noted, was completely eviscerated. The superior cervical sympathetic ganglion was removed from each side. In the removal care was exercised to avoid distortion of the tissue, for mechanical injury to the ganglion is likely to affect the size and shape of its cells. As the ganglion is small, it was deemed necessary to remove it in the mass of other tissues which closely invest it.

Both ganglia from each rat were prepared, but only one was used for measurements. No distinction between right and left was made in the record.

Aiming at a satisfactory preservation of the natural size of the cells, I followed King's ('10) recommendation of Bouin's solution for fixation. The ganglia from older rats were fixed in the solution for twenty-four hours, while for those from the younger ones - from birth to twenty-five days old--the period was reduced to twelve hours. Such a reduction of the fixation period has given satisfactory results.

The specimen was washed in different grades of alcohol, from 70 to 98 per cent, containing a small amount of carbonate of lithium. By so doing the yellow tinge given to the tissue by the fixation was completely removed. The specimen stayed in the alcohols of lower grades for twelve or more hours, and in the 90 and 98 per cent alcohol for about one hour. It was finally transferred to cedar oil for twenty-four hours for complete dehydration. Paraffin of $52^{\circ}$ was used for imbedding. By employing an electric bulb above the container the paraffin was kept melted only in its upper layer in the jar, the specimen sinking to the contact line between the melted and unmelted paraffin.

Under these conditions the specimen could be left in the paraffin for thorough penetration as long as seemed necessary without danger of overheating. 
Serial sections of the entire ganglion were cut $8 \mu$ in thickness. Heat from an electric bulb was used in flattening the sections. The slide was placed underneath the bulb, so that the water that served to float the sections on the slide, also chilled them from beneath, when they were spread by the heat.

The procedure in staining was as follows: The sections were passed from xylol down through the graded alcohols to water, and then put for five minutes in a saturated solution of lithium carbonate, after which they were stained for two or three minutes in a one-third saturated solution of thionin. They were then passed up through the graded alcohols to xylol and mounted in acid-free balsam. So far as possible, the plane of section was made perpendicular to the short axis of the ganglion, thus giving the maximum area.

\section{MEASUREMENTS OF THE CELLS AND NUCLEI}

The cells and nuclei of the ganglion were measured with an eyepiece micrometer, using a Zeiss ocular no. 6, and objective, $4 \mathrm{~mm}$. Each division in the micrometer scale was equivalent to $4.47 \mu$. The measurements were made in the following way: In the case of each specimen a section at the middle of the series was selected. Starting both ways from this, four more sections were selected, two in each direction, by skipping every other section. In this manner five sections altogether were chosen and marked for study. In each of the five sections the two largest cells were measured; thus ten cells in all were measured in each ganglion.

There were four principal points kept in mind when selecting the cells for study: First, the cells must be the largest in the section; second, they must be uninuclear; third, the nucleus must be located at or near the center of the cell and must be fairly large; fourth, in the nucleus at least one nucleolus must be present.

Under these conditions, the measurements made on the cells and nuclei are considered to represent the maximal longitudinal and transverse diameters of each cell and nucleus taken close to their median planes. It was often found in this study that 
the boundaries of a cell body were obscure. Furthermore, the distribution of the Nissl granules was rather irregular (as will be described later), so that neither the longitudinal nor the transverse diameter could be measured according to the extent of the stainable mass.

After the measurements had been taken, a sketch of the section with the two cells measured therein was made, and the nucleoli in these cells were noted, so that in making measurements for the second time the same cells could be identified by their location and the number of the nucleoli. As a matter of routine, the cells in each ganglion were measured twice, a considerable time being allowed to elapse between the first and second measurements. The procedure in measuring did not follow in the order of age or of body weight of the animal, as given in the tables, but was purposely haphazard, and in making measurements for the second time, the records were taken without referring to those already made. The values used are the means of the two series.

By this procedure prejudice was avoided and a more accurate determination of the size of the cells and nuclei obtained. The records thus made were tabulated in detail, but the averages of the values for the ten cells in each ganglion are those used for the tables, charts, and discussion which follow. The individual data have been filed in the archives of The Wistar Institute.

The square roots of the products of the longitudinal and transverse diameters of the cells and of the nuclei, respectively, for each ganglion were averaged, and the mean was multiplied by 4.47 , the value in $\mu$ of one division of the eyepiece scale. In table 1 the diameters of the cells and nuclei thus computed are arranged according to age, and in table 2 according to the body weight of the animal.

Based on the records in tables 1 and 2, charts 1 and 2 were plotted. Chart 1 shows on age the graphs for the diameter of the cells and nuclei in micra and chart 2 the same relations on body weight.

In the graphs for the cells in chart 1 we see in the increase before puberty only chance variations between the male and the female in diameter of the cell body, but after the rat has attained 
the age of eighty days (body weight about 100 grams) which is the period of puberty (Donaldson, '15, The Rat, p. 21) there appears a tendency for the cells to be larger in the female than in the male. It will be noted, however, that at the age of eightynine days, and also at 250 days, the male exhibits larger cells than the female of the same age. This discrepancy is explained when we take the body weights of the males into consideration. As given in table 1, the body weight of the male rat eighty-nine days old is twice that of the female of the same age, and the discrepancy is even greater in the case of the male at 250 days.

These males should be expected to have larger nerve cells by virtue of their body weight, and when a correction is made for it, the values for the male cells should fall below those for the female at these ages also. In general one may say that the female, after reaching puberty, has these cells larger than the male, if the body weight of the male does not too greatly exceed that of the female. As regards the nucleus, however, chart 1 exhibits a less clearly marked sex difference.

The fact that there is a better growth of the cell bodies in the female is more clearly illustrated in chart 2 , in which graphs for the diameters of the cells and nuclei have been plotted on body weight. From birth to the time just before puberty, the variations in the growth of these cells in the two sexes are similar to those shown in chart 1.

Just before puberty, when the rat weighs about 60 grams, the female becomes gradually more advanced in the growth of these cells and overtakes the male of the same body weight. The growth of the nerve cells in the female also shows a more regular course than that of the male. The growth of the nuclei at the corresponding ages of the two sexes follows in the same manner as that of the cell bodies, although the difference is relatively small.

It is proper to keep in mind, however, that when the comparison is made on the basis of body weight, the female is normally the older, and, further, that in several other growth changes the female tends to be precocious; both of these influences would tend to produce larger cells in the female under these conditions. 
TARLE 1

Computed diameters of the largest cells and nuclei according to age. From the superior cervical sympathetic ganglion of the albino rat

\begin{tabular}{|c|c|c|c|c|c|c|}
\hline \multirow{3}{*}{$\operatorname{sex}$} & \multirow{3}{*}{$\begin{array}{l}\mathrm{A} \\
\mathbf{A G E}\end{array}$} & \multirow{3}{*}{$\begin{array}{c}\text { B } \\
\text { BODY } \\
\text { WEIGHT }\end{array}$} & \multirow{3}{*}{$\begin{array}{c}\text { c } \\
\text { BODY } \\
\text { LENGTH }\end{array}$} & D & $\mathbf{E}$ & \multirow{3}{*}{$\begin{array}{c}F \\
\text { RATIO OF } \\
\text { DIAMETER OF } \\
\text { NUCEEUS TO } \\
\text { DIAM ETER OF CELI }\end{array}$} \\
\hline & & & & \multicolumn{2}{|c|}{ Computed diameter in $\mu$} & \\
\hline & & & & Cell & Nucleus & \\
\hline & $d a y s$ & grams & $m m$. & & & \\
\hline $0^{7}$ & 1 & 5.6 & 50 & 19.5 & 11.4 & $1: 1.72$ \\
\hline$q$ & 1 & 6.3 & 51 & 19.8 & 10.2 & $1: 1.93$ \\
\hline$\sigma^{\pi}$ & 5 & 9.0 & 63 & 22.1 & 10.7 & $1: 2.06$ \\
\hline q & 5 & 11.0 & 65 & 21.3 & 10.5 & $1: 2.03$ \\
\hline$\sigma^{7}$ & 11 & 15.0 & 77 & 24.9 & 13.1 & $1: 1.90$ \\
\hline$q$ & 11 & 14.0 & 73 & 26.4 & 13.1 & $1: 2.02$ \\
\hline$a^{\pi}$ & 16 & 18.9 & 83 & 25.3 & 13.1 & $1: 1.92$ \\
\hline \% & 16 & 19.0 & 81 & 23.1 & 11.2 & $1: 2.06$ \\
\hline$\sigma^{\pi}$ & 20 & 31.7 & 102 & 26.4 & 12.5 & $1: 2.11$ \\
\hline$q$ & 20 & 29.5 & 99 & 23.6 & 11.8 & $1: 1.99$ \\
\hline$\sigma^{\pi}$ & 25 & 23.8 & 93 & 26.6 & 12.6 & $1: 2.11$ \\
\hline q & 25 & 25.5 & 95 & 27.3 & 12.7 & $1: 2.15$ \\
\hline $0^{7}$ & 29 & 40.7 & 112 & 27.1 & 12.0 & $1: 2.26$ \\
\hline & 29 & 16.4 & 82 & 24.8 & 12.2 & $1: 2.03$ \\
\hline$\sigma^{7}$ & 42 & 61.4 & 129 & 27.0 & 13.4 & $1: 2.01$ \\
\hline \& & 42 & 43.5 & 105 & 27.2 & 13.2 & $1: 2.05$ \\
\hline$\sigma^{7}$ & 48 & 105.1 & 156 & 29.0 & 13.4 & $1: 2.17$ \\
\hline ๆ & 48 & 49.7 & 120 & 27.0 & 13.1 & $1: 2.05$ \\
\hline$d^{7}$ & 60 & 51.6 & 124 & 27.2 & 13.2 & $1: 2.06$ \\
\hline \& & 62 & 53.8 & 117 & 27.1 & 13.1 & $1: 2.07$ \\
\hline$d^{x}$ & 81 & 63.3 & 128 & 27.4 & 13.3 & $1: 2.06$ \\
\hline$\subsetneq$ & 80 & 83.7 & 142 & 26.6 & 12.8 & $1: 2.09$ \\
\hline व & 89 & 143.5 & 173 & 32.4 & 13.0 & $1: 2.49$ \\
\hline \% & 88 & 73.0 & 135 & 29.2 & 13.2 & $1: 2.21$ \\
\hline$d$ & 124 & 151.1 & 174 & 27.1 & 13.0 & $1: 2.08$ \\
\hline প & 124 & 107.1 & 157 & 30.5 & 13.8 & $1: 2.21$ \\
\hline $0^{7}$ & 171 & 198.2 & 192 & 27.0 & 13.1 & $1: 2.05$ \\
\hline$q$ & 171 & 123.8 & 159 & 30.9 & 12.8 & $1: 2.41$ \\
\hline $0^{x}$. & 250 & 230.0 & 207 & 36.8 & 15.4 & $1: 2.38$ \\
\hline 우 & 250 & 98.0 & 160 & 30.6 & 14.2 & $1: 2.15$ \\
\hline$\sigma^{7}$ & 365 & 186.0 & 203 & 29.6 & 13.5 & $1: 2.20$ \\
\hline$q$ & 365 & 170.6 & 186 & 31.4 & 13.5 & $1: 2.31$ \\
\hline$q$ & 540 & 151.3 & 184 & 30.7 & 13.4 & $1: 2.29$ \\
\hline ᄋ & 570 & 127.1 & 169 & 33.4 & 14.3 & $1: 2.34$ \\
\hline
\end{tabular}


On examining the ratios between the values at one day and at 365 days, as shown in columns.D and $\mathrm{E}$ of table 1 , it is found that the cells in the male have increased in diameter 1.55 times, and in the female 1.58 times, while the nuclei in the male have increased 1.17 times and in the female 1.32 times. This shows that the difference between the male and female in the growth of the nuclei in the course of one year is greater than that in growth of the cells, but the cells in both sexes have a greater rate of growth than do the nuclei, as indicated in table 1.

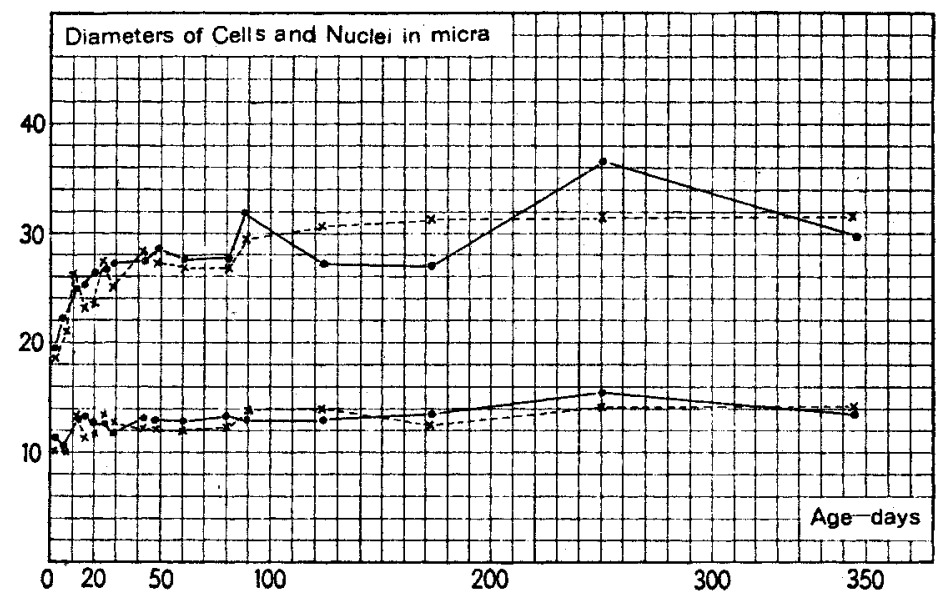

Chart 1. Based on table 1 and giving the computed diameters of the cells and their nuclei according to sex-on age in days. Males

Females

The graphs in chart 1 show that the increase in the diameter of the cell body is rapid for the first twenty-five days and then becomes slower. There is a similar change in the nucleus, though the change in the rate of growth in this case is less marked. From 25 to 365 days the diameters of the cells and of the nuclei of the two sexes have increased as shown in table 3 .

In column $\mathrm{F}$ of table 1 are given the ratios between the diameter of the cell body and that of the nucleus. Generally speaking, the cell has about twice the diameter of the nucleus throughout the series of measurements as given in table 1 , but if we consider the ratios carefully, we see that there is an increase in the ratios 
TABLE 2

Computed diameters of the largest cells and nuclei-on body weight-together with the nucleus plasma ratios-from the superior cervical sympathetic ganglion of the albino rat

\begin{tabular}{|c|c|c|c|c|c|c|}
\hline \multirow{3}{*}{ sex } & \multirow{3}{*}{$\begin{array}{c}A \\
A G E\end{array}$} & \multirow{3}{*}{$\begin{array}{c}\text { B } \\
\text { BODY } \\
\text { WEIGHT }\end{array}$} & \multirow{3}{*}{$\begin{array}{c}\text { C } \\
\text { BODY } \\
\text { LENGTH }\end{array}$} & D & $\mathrm{T}$ & \multirow{3}{*}{$\begin{array}{l}\text { NOCLEUB PLASM } \\
\text { RATIOS }\end{array}$} \\
\hline & & & & \multicolumn{2}{|c|}{ Computed diameter in $\mu$} & \\
\hline & & & & Cell & Nucleus & \\
\hline & days & grams & $m m$ & & & \\
\hline$\sigma^{x}$ & 1 & 5.6 & 50 & 19.5 & 11.4 & $1: 4.0$ \\
\hline 9 & 1 & 6.3 & 51 & 19.8 & 10.2 & $1: 6.3$ \\
\hline 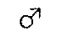 & 5 & 9.0 & 63 & 22.1 & 10.7 & $1: 7.8$ \\
\hline q & 5 & 11.0 & 65 & 21.3 & 10.5 & $1: 7.3$ \\
\hline 9 & 11 & 14.0 & 73 & 26.4 & 13.1 & $1: 7.2$ \\
\hline $0^{7}$ & 11 & 15.0 & 77 & 24.9 & 13.1 & $1: 5.8$ \\
\hline P & 29 & 16.4 & 82 & 24.8 & 12.2 & $1: 6.8$ \\
\hline$\sigma^{\pi}$ & 16 & 18.9 & 83 & 25.3 & 13.1 & $1: 6.2$ \\
\hline 9 & 16 & 19.0 & 81 & 23.1 & 11.2 & $1: 7.7$ \\
\hline$\sigma^{7}$ & 25 & 23.8 & 93 & 26.6 & 12.6 & $1: 8.4$ \\
\hline$q$ & 25 & 25.5 & 95 & 27.3 & 12.7 & $1: 8.9$ \\
\hline 9 & 20 & 29.5 & 99 & 23.6 & 11.8 & $1: 7.0$ \\
\hline $0^{7}$ & 20 & 31.7 & 102 & 26.4 & 12.5 & $1: 8.0$ \\
\hline$\sigma^{\pi}$ & 29 & 40.7 & 112 & 27.1 & 12.0 & $1: 10.5$ \\
\hline O & 42 & 43.5 & 105 & 27.2 & 13.2 & $1: 7.7$ \\
\hline 웅 & 48 & 49.7 & 120 & 27.0 & 13.1 & $1: 7.7$ \\
\hline $0^{7}$ & 60 & 51.6 & 124 & 27.2 & 13.2 & $1: 7.7$ \\
\hline 9 & 62 & 53.8 & 117 & 27.1 & 13.1 & $1: 7.8$ \\
\hline 8 & 42 & 61.4 & 129 & 27.0 & 13.4 & $1: 7.2$ \\
\hline 8 & 81 & 63.3 & 128 & 27.4 & 13.3 & $1: 7.5$ \\
\hline 우 & 88 & 73.0 & 135 & 29.2 & 13.2 & $1: 9.8$ \\
\hline 우 & 80 & 83.7 & 142 & 26.6 & 12.8 & $1: 7.9$ \\
\hline 우 & 250 & 98.0 & 160 & 30.6 & 14.2 & 1: 9.0 \\
\hline$\sigma^{\pi}$ & 48 & 105.1 & 156 & 29.0 & 13.4 & $1: 9.1$ \\
\hline 9 & 124 & 107.1 & 157 & 30.5 & 13.8 & $1: 9.8$ \\
\hline 움 & 171 & 123.8 & 159 & 30.9 & 12.8 & $1: 13.1$ \\
\hline 9 & 570 & 127.1 & 169 & 33.4 & 14.3 & $1: 11.7$ \\
\hline $0^{7}$ & 89 & 143.5 & 173 & 32.4 & 13.0 & $1: 14.4$ \\
\hline$\sigma^{7}$ & 124 & 151.1 & 174 & 27.1 & 13.0 & $1: 8.0$ \\
\hline 우 & 540 & 151.3 & 184 & 30.7 & 13.4 & $1: 11.0$ \\
\hline 우 & 365 & 170.6 & 186 & 31.4 & 13.5 & $1: 11.6$ \\
\hline$\sigma^{7}$ & 365 & 186.0 & 203 & 29.6 & 13.5 & $1: 9.5$ \\
\hline$\sigma^{7}$ & 171 & 198.2 & 192 & 27.0 & 13.1 & $1: 7.7$ \\
\hline$\sigma^{7}$ & 250 & 230.0 & 207 & 36.8 & 15.4 & $1: 12.6$ \\
\hline
\end{tabular}


as age advances, as they are, respectively, $1: 1.72$ and $1: 1.93$ for the youngest male and female; $1: 2.11$ and $1: 2.15$ at twentyfive days, and $1: 2.34$ for the oldest female.

This increase is therefore most marked during the first twentyfive days. By comparing the progress from birth to twenty-five days with that from twenty-nine days to 365 days, one can appreciate the rapid increase in amount of cytoplasm within the former period, as contrasted with the slower increase in the course

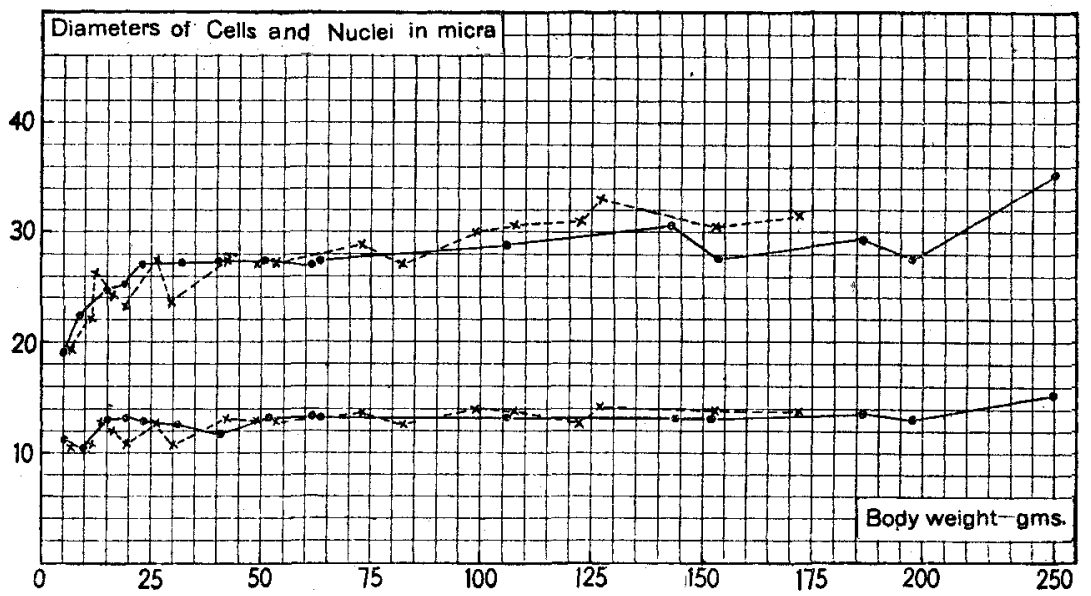

Chart 2 Based on table 2 and giving the computed diameters of the cells and their nuclei according to sex-on body weight. Males

Females

of a much longer time. It is fair to say, therefore, that the ratios shange but slowly after the first twenty-five days. This agrees with the statement of Donaldson and Nagasaka ('18) on the ventral horn cells, that after twenty-four days the nucleusplasma ratio increases but slowly.

\section{VARIABILITY WITHIN A GIVEN GANGLION}

The number of large cells examined in each ganglion is hardly great enough to permit of satisfactory statistical treatment, but it has been thought worth while to tabulate for each animal the range and average of the diameters of the cells and of the 
nuclei, entering these according to age as in table 1 . In a fairly graded series of measurements we may expect to find the average for the series close to the mean of the limiting values, and a little study of table 4 shows this to be the case.

\section{MORPHOLOGY OF THE LARGE CELLS}

Plate 1. (Figures 1 to 7 )

In considering the morphology of the cells in the superior cervical sympathetic ganglion, it must be recalled that from its cells arise several classes of fibers-pupillodilator fibers, motor, vasomotor, pilomotor and secretory fibers. It is a priori possible,

TABLE 3

Increase in diameters of cells and nuclei from 25 to 365 days

\begin{tabular}{|c|c|c|c|c|c|}
\hline \multirow{2}{*}{ DIAMETERS } & \multirow{2}{*}{$\operatorname{sex}$} & \multirow{2}{*}{25 DAYS } & \multirow{2}{*}{365 D $\triangle \times S$} & \multicolumn{2}{|c|}{ GAIN } \\
\hline & & & & Absolute & Percentage \\
\hline \multirow{3}{*}{ Cells. } & & $\mu$ & $\mu$ & $\mu$ & \\
\hline & $0^{\pi}$ & 26.59 & 29.60 & 3.01 & 11.3 \\
\hline & 우 & 27.26 & 31.38 & 4.12 & 15.1 \\
\hline \multirow{2}{*}{ Nuclei. } & $0^{\pi}$ & 12.60 & 13.45 & 0.85 & 6.31 \\
\hline & 우 & 12.65 & 13.54 & 0.89 & 6.58 \\
\hline
\end{tabular}

that the several functions thus indicated are correlated with cell characters that are distinctive, but at the moment we have nothing to contribute to the solution of this problem.

When young, the cells of the superior cervical ganglion are very similar in appearance to those of the young spinal ganglion, and practically all of them are more or less elongated with processes at one or both ends. Each cell has a large clear nucleus surrounded by a little cytoplasm. This cytoplasm is homogeneous in structure and stains uniformly. Those coarse Nissl bodies, which are found in the cells at later ages, are totally lacking. Usually each nucleus has a single, dark stained, nucleolus, but occasionally there may be found more than one. This condition continues from birth to five or six days of age, when differentiation begins in the cytoplasm of these immature cells. 
TABLE 4

Giving the ranges in the values for the diameters of the largest cells and their nuclei in the superior cervical sympathetic ganglion of the albino ratarranged according to sex and age

\begin{tabular}{|c|c|c|c|c|c|c|}
\hline \multirow{2}{*}{$\operatorname{sex} X$} & \multirow{2}{*}{$A G E$} & \multirow{2}{*}{$\begin{array}{c}\text { BODY } \\
\text { WEIGHT }\end{array}$} & \multicolumn{2}{|c|}{ CEILS } & \multicolumn{2}{|c|}{ NUCLEI } \\
\hline & & & Diameter & Range & Diameter & Range \\
\hline & days & grams & $\mu$ & $\mu$ & $\mu$ & $\mu$ \\
\hline$\sigma^{7}$ & 1 & 5.6 & 19.5 & $22.0-18.0$ & 11.4 & $14.0-9.4$ \\
\hline q & 1 & 6.3 & 19.8 & $24.0-17.4$ & 10.2 & $12.0-9.4$ \\
\hline $0^{\pi}$ & 5 & 9.0 & 22.1 & $25.0-20.0$ & 10.7 & $14.0-9.0$ \\
\hline$q$ & 5 & 11.0 & 21.3 & $25.0-18.3$ & 10.5 & $12.3-9.0$ \\
\hline q & 11 & 14.0 & 26.4 & $30.0-23.0$ & 13.1 & $15.0-11.0$ \\
\hline$\sigma^{7}$ & 11 & 15.0 & 24.9 & $30.4-22.0$ & 13.1 & $13.7-11.6$ \\
\hline$\sigma^{7}$ & 16 & 18.9 & 25.3 & $29.0-22.0$ & 13.1 & $14.0-12.0$ \\
\hline † & 16 & 19.0 & 23.1 & $25.0-20.3$ & 11.2 & $14.0-10.0$ \\
\hline 우 & 20 & 295.0 & 23.6 & $27.0-19.4$ & 11.8 & $16.0-10.4$ \\
\hline $0^{x}$ & 20 & 317.0 & 26.4 & $29.0-24.0$ & 12.5 & $14.0-11.0$ \\
\hline$\sigma^{7}$ & 25 & 238.0 & 26.6 & $31.0-23.0$ & 12.6 & $14.0-11.0$ \\
\hline$q$ & 25 & 25.5 & 27.3 & $31.0-24.7$ & 12.7 & $14.0-11.0$ \\
\hline q & 29 & 16.4 & 24.8 & $26.0-22.7$ & 12.2 & $14.0-9.4$ \\
\hline $0^{2}$ & 29 & 40.7 & 27.1 & $30.0-24.7$ & 12.0 & $14.0-10.0$ \\
\hline 웅 & 42 & 43.5 & 27.2 & $31.0-24.7$ & 13.2 & $16.0-11.0$ \\
\hline $0^{\pi}$ & 42 & 61.4 & 27.0 & $30.0-24.7$ & 13.4 & $16.0-12.0$ \\
\hline 우 & 48 & 49.7 & 27.0 & $29.0-24.7$ & 13.1 & $15.0-9.0$ \\
\hline $0^{7}$ & 48 & 105.1 & 29.0 & $33.0-26.4$ & 13.4 & $15.0-12.6$ \\
\hline $0^{x}$ & 60 & 51.6 & 27.2 & $30.0-24.0$ & 13.2 & $15.0-12.4$ \\
\hline q & 62 & 53.8 & 27.1 & $30.0-24.0$ & 13.1 & $15.0-11.6$ \\
\hline q & 80 & 83.7 & 26.6 & $29.0-25.7$ & 12.8 & $13.7-11.6$ \\
\hline$\sigma^{7}$ & 81 & 63.3 & 27.4 & $31.5^{-25.7}$ & 13.3 & $15.6-11.0$ \\
\hline q & 88 & 73.0 & 29.2 & $31.0-26.0$ & 13.2 & $14.6-11.0$ \\
\hline $0^{7}$ & 89 & 143.5 & 32.4 & $36.7-28.5$ & 13.0 & $14.6-11.0$ \\
\hline$q$ & 124 & 107.0 & 30.5 & $33.0-29.0$ & 13.8 & $16.0-13.0$ \\
\hline $0^{7}$ & 124 & 151.1 & 27.1 & $28.5-25.0$ & 13.0 & $14.0-11.7$ \\
\hline 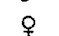 & 171 & 123.8 & 30.9 & $33.7-29.0$ & 12.8 & $13.7-9.7$ \\
\hline$\sigma^{7}$ & 171 & 198.2 & 27.0 & $32.4-24.7$ & 13.1 & $14.0-12.4$ \\
\hline q & 250 & 98.0 & 30.6 & $33.0-26.6$ & 14.2 & $16.0-14.0$ \\
\hline $0^{7}$ & 250 & 230.0 & 36.8 & $39.0-35.6$ & 15.4 & $18.0-14.4$ \\
\hline o & 365 & 170.6 & 31.4 & $38.0-28.5$ & 13.5 . & $15.6-12.3$ \\
\hline $0^{7}$ & 365 & 186.0 & 29.6 & $33.7-26.6$ & $13.5^{\circ}$ & $16.0-12.0$ \\
\hline 9 & 540 & 151.3 & 30.7 & $34.4-28.3$ & 13.4 & $14.7-11.0$ \\
\hline$q$ & 570 & 127.1 & 33.4 & $36.7-29.0$ & 14.3 & $16.0-14.0$ \\
\hline
\end{tabular}


At birth or during the first days of life there are found among the young cells a few advanced cells which appear conspicuously different from the rest. In these advanced cells the cytoplasm may be already differentiated, even at birth. The stainable Nissl granules, which are of course much finer than those found at later ages, are evenly but distinctly distributed through the entire contents of the cell. Among these granules some clear spaces appear which seem to indicate the differentiation of the homogeneous cytoplasmic mass, and this change in the advanced cells must have commenced during fetal life.

When the young cells begin to develop, there is the same differentiation of the cytoplasmic mass, and the stainable bodies arrange themselves in the same way as those seen in the advanced cells. Hereafter more differentaition will be found in them and they grow to resemble the advanced cells in appearance.

Taking this as the starting-point in the morphological development, we see among the comparatively large cells in the ganglion four types which probably appear one after the other as here given in the course of growth.

Type 1 . The advanced cells and the cells which are transforming into advanced cells, as described above, belong to this type. There is a beginning of aggregation of the Nissl granules and a growth of the unstainable ground-substance in the cells. This type is common during the first twenty days of postnatal life (fig. 2).

Type 2. The Nissl bodies are larger than in type 1 and aggregated at the periphery of the cells, forming a ring within which is a comparatively clear portion of the ground-substance surrounding the nucleus. The Nissl bodies stain much darker than in type 1. The nuclear membrane, the nucleoli, and the reticular structure in the nucleus are distinctly visible. There are frequently two or more nucleoli in one nucleus. This type is common in the period between twenty and sixty days (fig. 3), but may also be found at birth (fig. 1).

Type 3. Instead of being distributed at the periphery, the Nissl bodies are aggregated around the nucleus, leaving a rather clear space at the periphery of the cell. In some of the cells they 
are more crowded at certain regions close to the nucleus, forming dark masses, but some of them may be loosely scattered toward the periphery. It is in this type of cell that difficulties have often been encountered in making out the boundary between the cell wall and the supporting tissue, because the unstained ground-substance is chiefly distributed at the periphery of the cell. This type is common after twenty days of age, but is not infrequently found after sixty days (fig. 4).

Type 4. The cells resemble the first type in the arrangement of Nissl bodies, but the stainable bodies are much coarser. There is a considerable evenness in their distribution, though here and there we find a larger dark stainable mass resulting from their aggregation. Whether this type is developed from the preceding type through modifications in the course of development or whether it is directly derived from type 1 , without undergoing the various changes as in types 2 and 3 , is a matter to be settled through more detailed investigation (fig. 5). This type is characterized by the dense appearance of Nissl bodies throughout the entire cell body, not leaving much space for the groundsubstance, and is common at the age of 124 days and later.

In interpreting these several types it is to be recalled that the cells of this ganglion have several different functions and there always remains the possibility of a correlation between function and morphology.

Besides the four types of cells described above, binuclear cells are found at all ages until the rat is very old. In recording them, special care needs to be taken. As the cell wall of the sympathetic cell is at times difficult to distinguish, two uninuclear cells in close contract with each other may frequently resemble one cell with two nuclei. In order to avoid error due to such misleading appearances, the precaution has been taken to use an oil-immersion lens in distinguishing the true binuclear cells from those which resemble them. The cells which have their cytoplasm discontinuous somewhere between the nuclei or a constriction at the middle, either slight or pronounced, as the one figured by Apolant ('96, Majer's 'cell bridge,' fig. 8, pl. XXIII), were not considered as of the true binuclear type. 
TABLE 5

Giving the number of the cells with two nuclei and of the cells showing pigment, at different ages. Superior cervical sympathetic ganglion--albino rat. In each case the numbers are for one ganglion only

\begin{tabular}{|c|c|c|c|c|c|}
\hline $\operatorname{sex}$ & AGE & BODY WEIGHT & BODY LENGTH & $\left|\begin{array}{l}\text { NUMBER } \\
\text { OF RI- } \\
\text { NUCLEAAR CELLS }\end{array}\right|$ & $\begin{array}{l}\text { CELLS WITHI } \\
\text { PIGMENT }\end{array}$ \\
\hline & days & grams & $m m$. & & \\
\hline$\sigma^{x}$ & 1 & 5.6 & 50 & 2 & 0 \\
\hline q & 1 & 6.3 & 51 & 2 & 0 \\
\hline$\sigma^{7}$ & 5 & 9.0 & 63 & 1 & 0 \\
\hline q & 5 & 11.0 & 65 & 2 & 0 \\
\hline 8 & 11 & 15.0 & 77 & 1 & 0 \\
\hline 우 & 11 & 14.0 & 73 & 2 & 0 \\
\hline $0^{7}$ & 16 & 18.9 & 83 & 1 & 0 \\
\hline ㅇ & 16 & 19.0 & 81 & 1 & 0 \\
\hline$\sigma^{x}$ & 20 & 31.7 & 102 & 2 & 0 \\
\hline q & 20 & 29.5 & 99 & 4 & 0 \\
\hline$\sigma^{7}$ & 25 & 23.8 & 93 & 4 & 0 \\
\hline 우 & 25 & 25.5 & 95 & 3 & 0 \\
\hline $0^{7}$ & 29 & 40.7 & 112 & 3 & 0 \\
\hline 우 & 29 & 16.4 & 82 & 3 & 0 \\
\hline 0 & 42 & 61.4 & 129 & 5 & 0 \\
\hline q & 42 & 43.5 & 105 & 12 & 0 \\
\hline$\sigma^{7}$ & 48 & 105.1 & 156 & 4 & 0 \\
\hline 9 & 48 & 49.7 & 120 & 2 & 0 \\
\hline$\sigma^{x}$ & 60 & 51.6 & 124 & 5 & 0 \\
\hline 우 & 62 & 53.8 & 117 & 5 & 0 \\
\hline$\sigma^{\prime}$ & 81 & 63.3 & 128 & 3 & 0 \\
\hline q & 80 & 83.7 & 142 & 12 & 0 \\
\hline $0^{7}$ & 89 & 143.5 & 173 & 7 & 0 \\
\hline q & 88 & 73.0 & 135 & 1 & 1 \\
\hline $0^{7}$ & 124 & 151.1 & 174 & 15 & 8 \\
\hline 우 & 124 & 107.1 & 157 & 6 & 0 \\
\hline $0^{7}$ & 171 & 198.2 & 192 & 2 & 4 \\
\hline q & 171 & 123.8 & 159 & 9 & 0 \\
\hline $0^{\pi}$ & 250 & 230.0 & 207 & 4 & 0 \\
\hline 9 & 250 & 98.0 & 160 & 5 & 3 \\
\hline $0^{7}$ & 365 & 186.0 & 203 & 6 & 3 \\
\hline $9^{\circ}$ & 365 & 170.6 & 186 & 14 & 2 \\
\hline 웅 & 540 & 151.3 & 184 & 2 & 4 \\
\hline q & 570 & 127.1 & 169 & 3 & 13 \\
\hline
\end{tabular}


Every one of the cells recorded in table 5 had an unbroken layer of Nissl granules around the two nuclei, and at the middle of the cell there existed absolutely no trace of any partition whatsoever which might suggest the contiguous surfaces of two cells closely grown together. Figures 6 and 7 show the binuclear cells in a very young and in a comparatively old rat, respectively.

If we determine, by direct measurement, the nucleus-plasma relation in this particular older cell (fig. 7), contrasting the volume of both nuclei with that of the cytoplasm, we find a ratio of $1: 5.0$. This is almost as low as the ratio at birth, and indicates that we are dealing with an increase in the nuclear mass not accompanied by a corresponding increase in the cytoplasm. This, so far as it goes, is an argument against the suggestion that we have here two cells that are fused.

According to table 5, the occurrence of binuclear cells is not related to sex. In many cases the numbers of these cells in both sexes are equal or almost equal. There appears, however, to be an increase in their number toward middle age, ranging from sixty days to 365 days, with a possible decrease later.

Apolant found cells of the binuclear type in the superior cervical ganglion of an embryo rabbit three weeks old, and states that such cells persist in the older animal, when the cells have been completed anatomically and physiologically. According to him, this is the result of direct nuclear division; about half of the binuclear cells being formed during embryonic life and the remainder later. It is not the purpose of this paper to deal with the function and origin of this type of cells. Their appearance in the postnatal stages of the rat, as recorded in table 5, agrees with what Apolant points out as the course of the development of the cells in the later ages of the animal. Carpenter and Conel ('14) noted this type of cells in considerable number in the rabbit, guinea-pig, muskrat, and porcupine, but rarely, if ever, did they find them in the sympathetic ganglion of the rat.

As these authors' observations were made most probably on one or on only a few stages of the rat, the small number of such cells in the entire ganglion justifies their statement, in a way but nevertheless the presence of the binuclear cells in the superior cervical sympathetic of the rat is beyond question. 
Incidentally, pigmented cells have been noted in the superior sympathetic ganglion of the albino rat. The cells of comparatively young animals, from birth to eighty days, are entirely free from pigment. At the beginning of puberty we occasionally find pigment in one or two cells in an entire ganglion. The number of the pigmented cells tends to increase as age advances, as recorded in table 5 . Some of the cells are only partly pigmented; a few are completely covered with these granules, the nucleus remaining unaffected, while others are totally pigmented, including the nucleus. The pigments appear yellow brown, or, black in color, but whether this is merely a result of their relative abundance or whether there are several sorts of pigment has not been determined. The whole question of pigment in the Albino nervous system seems worthy of a special investigation.

INCREASE IN THE NUMBER OF THE LARGE CELLS

The increase in the number of the large cells in the ganglion during the first twenty days is an important event. This is chiefly due to the rapid increase in diameter of the young cells after ten or fifteen days of age. The large cells measure 19 to $25 \mu$ in diameter, and are loosely scattered and intermingled with small cells, as seen in each section. Disregarding their finer differences, such a group of cells consists of three kinds:

1. The advanced cells. During embryonic development it is known that the sympathetic trunks are formed through the migration of some cells which pass from the spinal cord along the paths of the communicating rami (Kuntz, '10). The advanced cells in the superior cervical ganglion are the forerunners of the neurones which come to this locality in "skirmish order-much in advance of the others" and "they represent but a fraction of the final number of large cells" (Donaldson, '17). The number of these cells during the first twenty days varies from one to eight in the entire ganglion.

2. The moderately large cells. These cells constitute an intermediate group between the advanced cells and the small cells in the same ganglion during the first ten days of age. They are not different from other younger cells in general structure and 
TABLE 6

Increase in number of large and advanced cells, 19 to $25 \mu$ in diameter, during the first twenty days of life. The ratios in the increase in the total number for both sexes between one day and twenty days stand at the foot of the column. Superior cervical sympathetic ganglion-albino rat

\begin{tabular}{|c|c|c|c|}
\hline SEX & $\triangle A G E$ & BODY WEIGHT & $\begin{array}{c}\text { NUMBER OF LARGE } \\
\text { CELLA AND OF } \\
\text { ADVANCED CEXIS }\end{array}$ \\
\hline & days & grams & \\
\hline $0^{x}$ & 1 & 5.6 & 188 \\
\hline ๑ & 1 & 6.3 & 174 \\
\hline$d^{x}$ & 5 & 9.0 & 289 \\
\hline$q$ & 5 & 11.0 & 306 \\
\hline $0^{x}$ & 11 & 15.0 & 291 \\
\hline$q$ & 11 & 14.0 & 301 \\
\hline$\sigma^{7}$ & 16 & 18.9 & 760 \\
\hline q & 16 & 19.0 & 584 \\
\hline$\sigma^{x}$ & 20 & 31.7 & 2508 \\
\hline 우 & 20 & 29.5 & 2248 \\
\hline
\end{tabular}

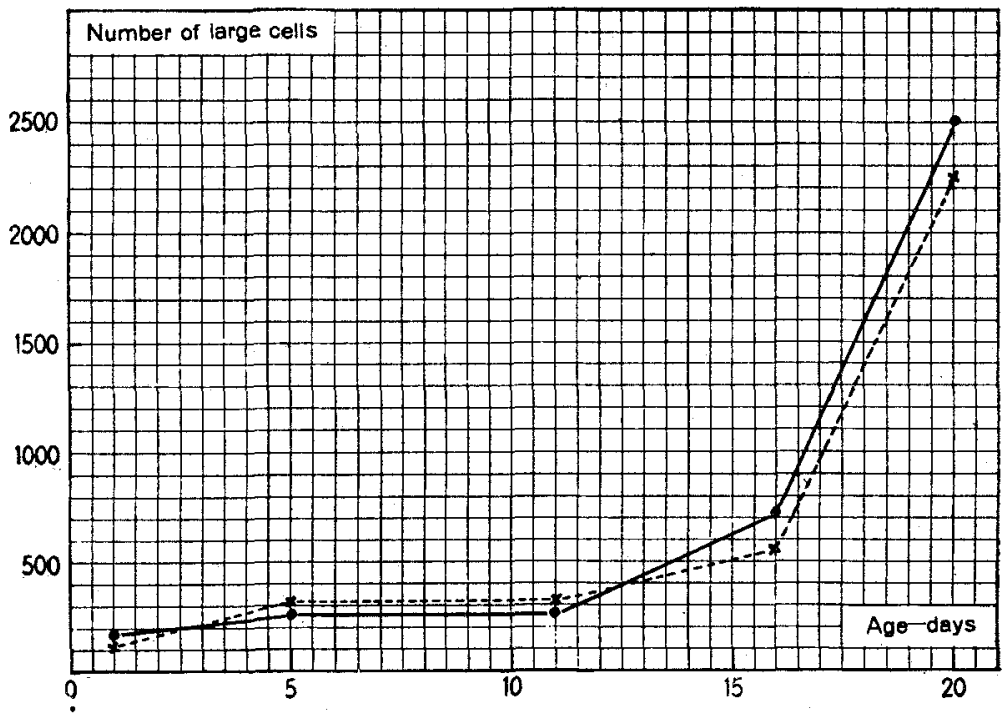

Chart 3 Based on table 6 and showing the number of large cells present in the superior cervical sympathetic ganglion of the albino rat from birth to twenty days of age. Males —. Females 
form, but they are distinguishable, owing to their larger size. It is this group of cells which will appear later as the advanced cells.

3. The growing small cells. These cells are small during the first five days after birth, but some of them grow very fast toward the end of twenty days, to a size equal to that of the other large cells. There is a constant increase in the number of these smaller cells which are growing.

For the determination of the rate of increase in the number of the large cells, 19 to $25 \mu$ in diameter, counting was undertaken. The cells counted comprised those just described under 1 and 2 . Since the same large cell does not appear in two successive sections, repetition in counting them is easily avoided. Table 6 gives the numbers of these cells. Based upon these numbers, the graphs in chart 3 were plotted on age. In chart 3 the male has a slightly higher rate of increase than has the female after twelve days. When the animal reaches sixteen days, both sexes show a more rapid increase, and the difference between them becomes more evident. If the data are plotted in a like manner on the body weight, they show similar relations. On the whole, then, the data show that the increase of large cells during the first sixteen days is relatively slow and afterward increasingly rapid. Between the age limits here given the increase in the number of large cells-sexes combined-is about thirteen-fold.

\section{THE TRANSFORMATION OF THE YOUNG CELLS}

During the later period of development there remain in this ganglion a number of young cells which, in contrast with the large cells, are slow in growth and which retain their neuroblastic appearance for a considerable length of time (fig. 1). As already noted, some nerve cells are precocious and many of them have attained their maximum size at the end of twenty to twenty-five days. It is most probable that the young cells found after twenty-five days of age are largely rudimentary elements, and some of them will never grow to the same size as the others. Yet some development is going on in both their structure and size, as is indicated by the constant decrease of their number 
TABLE 7

Showing the changes in the number of young cells from the period just prior to puberty to the end of one year. Superior cervical sympathetic ganglion-albino rat

\begin{tabular}{|c|c|c|c|}
\hline $\operatorname{sex}$ & $\triangle G E$ & BODY WEIGHT & $\underset{\text { CELLS }}{\text { NUMBER OF YOUNG }}$ \\
\hline & days & grams & \\
\hline $0^{\pi}$ & 60 & 51.6 & 470 \\
\hline$q$ & 62 & 53.8 & 471 \\
\hline $0^{7}$ & 89 & 143.5 & 362 \\
\hline$q$ & 88 & 73.0 & 345 \\
\hline$\sigma^{x}$ & 124 & 151.1 & 326 \\
\hline$q$ & 124 & 107.1 & 252 \\
\hline $0^{x}$ & 171 & 198.2 & 242 \\
\hline$\%$ & 171 & 123.8 & 207 \\
\hline $0^{7}$ & 365 & 186.0 & 105 \\
\hline$q$ & 365 & 170.6 & 102 \\
\hline & & $\begin{array}{l}1: 0.224 \\
1: 0.217\end{array}$ & \\
\hline
\end{tabular}

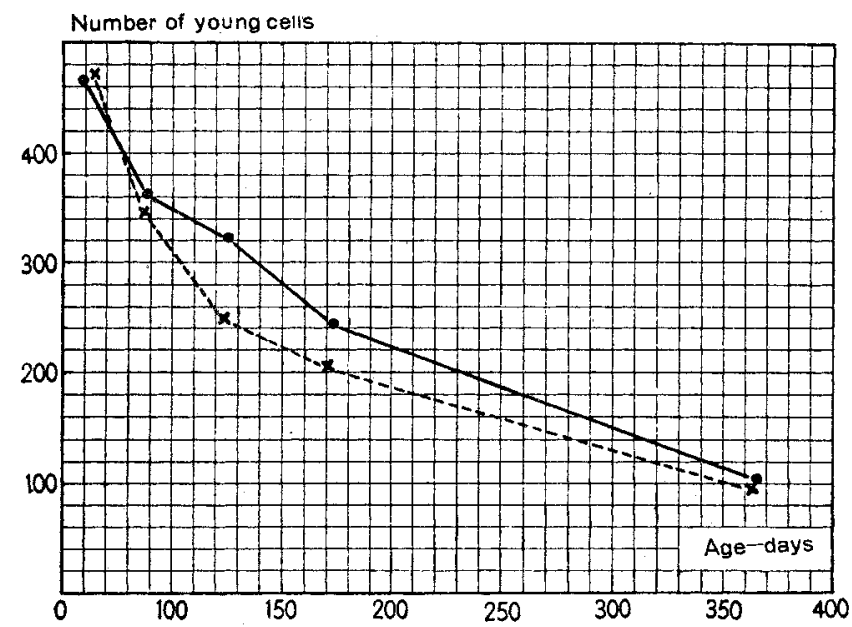

Chart 4 Based on table 7. Showing the changes in the number of young cells in the superior cervical sympathetic ganglion of the albino rat between sixty and 365 days of age. Males 
toward the end of one year. A study of the rate in the decrease of the young cells will serve as a means of measuring this change at later ages. For this purpose counting was undertaken. Because of their considerable number during the early prepubertal stage, as well as their small size and irregular distribution, it is almost impossible to obtain a satisfactory value by a single count, so that a second and a third count were usually made.

The numbers recorded in table 7 represent averages of three counts of young cells in each ganglion. The cells, selected and counted as young cells, have the following characters: They are 5 to $10 \mu$ in long diameter; more or less pyriform, and the cytoplasm is little differentiated.

The graphs in chart 4 represent the numbers of the cells as given in table 7 , on age. The decrease in number at first shows no tendency for one sex to outrun the other, but a difference appears soon after puberty, and such a difference in decrease of the young cells between the male and the female persists till the end of one year. The young cells of the female rat in relation to age are transformed more rapidly than those of the male; that is, these cells grow faster in the female. This phenomenon is in accord with what has been seen in the growth of large cells in diameter, as shown in charts 1 and 2 .

\section{DISCUSSION}

There is reason to think that at birth the full number of cells in the superior cervical sympathetic of the albino rat has been attained and that no more cells wander in and mitosis is finished. These cells appear to persist throughout the span of life.

Postnatal development of these cells consists in the enlargement of all parts of the neuron accompanied by differentiation. In the nucleus there is less change in size than in the cell body. The increase in number of nucleoli has been frequently noted, but it is not within the scope of the present paper to discuss this point.

Bringing the observations together, we see that the male and the female do not differ clearly from each other in the growth of these nerve cells until the animal has become sexually mature. 
The rate of increase in the number of the large cells in the superior cervical ganglion is, if anything, a little lower in the females before twenty days and a little higher later. On the other hand, the increase in size shows only chance variations during the first seventy days. These variations are subject to the influence of both age and body weight of the young animal, but puberty is attained, sex begins to be significant in addition to the other two factors.

If there is not too much difference between the ages and the body weights of the male and of the female, then the difference found in the quantitative development of the cytoplasm between the two may be attributed to this influence of sex. In table 8

TABLE 8

Giving, according to sex, the average computed diameters of the cell and the nucleus for three groups of body weights of albino rats. In the last column are given the ratios between the cell and the nucleus diameters. Data condensed from table. 2

\begin{tabular}{|c|c|c|c|c|c|}
\hline \multirow{2}{*}{$\mathrm{sEx}$} & \multirow{2}{*}{$\begin{array}{c}\text { NUMBER oF } \\
\text { CASES }\end{array}$} & \multirow{2}{*}{ BODY WEIGHT } & \multicolumn{2}{|c|}{ DIAMETERs } & \multirow{2}{*}{$\begin{array}{c}\text { RATIO OF } \\
\text { DrAMETER OF } \\
\text { NUCLEUS TO GELL }\end{array}$} \\
\hline & & & Cell & Nucleus & \\
\hline & & grams & $\mu$ & $\mu$ & \\
\hline$\sigma^{7}$ & 4 & $5.6-18.9$ & 22.9 & 12.1 & $1: 1.89$ \\
\hline$\%$ & 5 & $6.3-19.0$ & 23.1 & 11.4 & $1: 2.03$ \\
\hline$\sigma^{4}$ & 7 & $23.8-105.1$ & 27.2 & 12.9 & $1: 2.11$ \\
\hline q & 9 & $25.5-107.0$ & 27.7 & 13.1 & $1: 2.11$ \\
\hline $0^{7}$ & 5 & $143.5-230.0$ & 30.6 & 13.6 & $1: 2.25$ \\
\hline 9 & 4 & $123.8-170.6$ & 31.6 & 13.5 & $1: 2.34$ \\
\hline
\end{tabular}

is given a condensed statement of the cell measurements according to sex, based on body weights as these appear in table 2. For the cell body the values are in favor of the female for all three groups.

After puberty the sympathetic neurons in the female tend to have larger cell bodies and the small cells transform more rapidly.

At the moment it would not be wise to infer that similar relations would be found in other sympathetic ganglia or in other strains of rats; nevertheless, as they stand, the results agree with the suggestion of Dunn ('12) that the mass of the periphera] nervous system in the female albino rat is greater in proportion to the body weight than in the male. 
In table 9 are given the amounts by which the cell diameters of the females differ from those for the males at four ages after eighty days. The mean excess for the females is about 6.9 per cent, which represents approximately an excess of 20 per cent in volume. When a corresponding comparison is made for the diameters of the nuclei in these four groups, the average difference according to sex is feund to be zero.

TABLE 9

Showing, in four age groups, the absolute and percentage difference in the cell diameters of the largest cells in the superior cervical sympathetic ganglion of the female albino rat as compared with the male, based on the values in table 1 . Because of the great difference in the body weights, the data for the group at 250 days are omitted

\begin{tabular}{|c|c|c|}
\hline \multirow{2}{*}{$A G E$} & \multicolumn{2}{|c|}{ CELL DIAMETER IN THE FEMALE DIFFERS FROM THAT IN THE MALE BY } \\
\hline & Absolute $\mu$ & Percentage \\
\hline days & & r \\
\hline 80 & -0.8 & -3.0 \\
\hline 124 & +2.6 & +9.6 \\
\hline 171 & +3.9 & +14.4 \\
\hline 365 & +1.8 & +6.0 \\
\hline \multicolumn{2}{|l|}{ Average . } & +6.9 \\
\hline
\end{tabular}

On the size of these cells in the inbred albino rat

To determine whether the size relations according to sex which have just been described for albino rats belonging to the socalled 'standard strain' are generally found, a series of inbred Albinos was examined, for comparison.

The specimens used in this study were furnished by Dr. Helen D. King. These rats had been closely inbred for thirty-four to thirty-five generations. Seven pairs were used, ranging from eighty-nine days to 154 days and each pair was from the same litter. The preparation of the specimens was made in the same manner as that for the series just described.

The records on sex, age, body weight and length and the measurements of the cells and nuclei are given in the following table 10 . 
Using table 10, chart 5 was plotted on age. The graphs show a slight difference in the size of the cells of the male and female. The male, as indicated by the graphs, seems to have a better growth in the cytoplasm than the female of the same age, but the difference is small and cannot be considered as primarily

TABLE 10

Data on the inbred albino rats from the colony of Doctor King. Diameters of largest cells in the superior cervical sympathetic ganglion-on age

\begin{tabular}{|c|c|c|c|c|c|c|}
\hline \multirow{2}{*}{$\operatorname{sex}$} & \multirow{2}{*}{$\mathbf{A G E}$} & \multirow{2}{*}{$\begin{array}{c}\text { BODY } \\
\text { WEIGHT }\end{array}$} & \multirow{2}{*}{$\begin{array}{c}\text { BODY } \\
\text { LENGTH }\end{array}$} & \multicolumn{2}{|c|}{ DIAMETERS } & \multirow{2}{*}{$\begin{array}{c}\text { RATIO OF } \\
\text { DIAMETER OF } \\
\text { NUCLEUS TO GELL }\end{array}$} \\
\hline & & & & Cell & Nucleus & \\
\hline & & & & $\mu$ & $\mu$ & \\
\hline$\sigma^{\pi}$ & 89 & 144 & 176 & 21.90 & 12.90 & $1: 1.69$ \\
\hline$q$ & 89 & 100 & 156 & 21.60 & 13.00 & $1: 1.66$ \\
\hline$\sigma^{r}$ & 103 & 232 & 202 & 24.60 & 14.05 & $1: 1.75$ \\
\hline q & 103 & 203 & 189 & 24.20 & 13.25 & $1: 1.82$ \\
\hline$\sigma^{-x}$ & 123 & 206 & 193 & 24.70 & 13.12 & $1: 1.88$ \\
\hline 우 & 123 & 176 & 187 & 24.21 & 13.14 & $1: 1.84$ \\
\hline$\sigma^{3}$ & 116 & 140 & 177 & 23.21 & 12.60 & $1: 1.84$ \\
\hline 우 & 116 & 110 & 172 & 22.81 & 12.50 & $1: 1.82$ \\
\hline $0^{\pi}$ & 131 & 310 & 220 & 28.80 & 14.00 & $1: 2.07$ \\
\hline q & 131 & 205 & 192 & 26.00 & 13.50 & $1: 1.92$ \\
\hline $0^{7}$ & 136 & 179 & 188 & 24.80 & 12.79 & $1: 1.94$ \\
\hline 우 & 136 & 148 & 182 & 25.80 & 13.79 & $1: 1.87$ \\
\hline $0^{7}$ & 154 & 251 & 212 & 27.21 & 15.21 & $1: 1.79$ \\
\hline 웅 & 154 & 188 & 189 & 26.00 & 13.45 & $1: 1.93$ \\
\hline
\end{tabular}

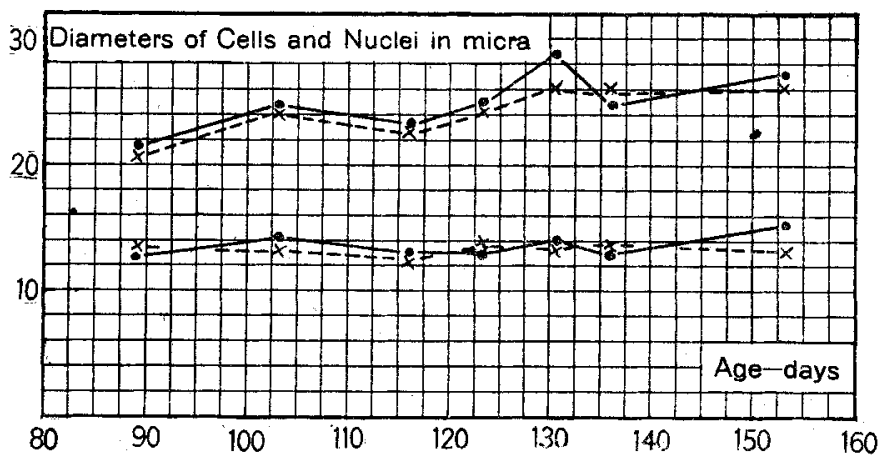

Chart 5 Based on table 10. Showing the computed diameters of the cells and their nuclei, according to sex, on age in days (inbred Albino). Male- Female 
due to sex, because in each pair the male has a greater body weight than the female.

In table 11 the data have been arranged according to body weight. Using these, chart 6 was plotted. In only one instance is the value for the female below that for the male in the case of the cells, while the female values for the nuclei are always above those for the male.

TABLE 11

Giving the computed diameters of the cells and their nuclei arranged according to body weight. The same data as in table 10. Inbred albino rats.

\begin{tabular}{|c|c|c|c|c|c|c|}
\hline \multirow{2}{*}{$\operatorname{sex}$} & \multirow{2}{*}{$\mathrm{AGE}$} & \multirow{2}{*}{$\begin{array}{l}\text { BODY } \\
\text { WEIGET }\end{array}$} & \multirow{2}{*}{$\begin{array}{c}\text { BODY } \\
\text { LENGTH }\end{array}$} & \multicolumn{2}{|c|}{ DIAMETERS } & \multirow{2}{*}{$\begin{array}{l}\text { NUCLEUS PLASMA } \\
\text { RATIOS }\end{array}$} \\
\hline & & & & Cell & Nucleus & \\
\hline & & & & $\mu$ & $\mu$ & \\
\hline$q$ & 89 & 100 & 156 & 21.60 & 13.00 & $1: 2.6$ \\
\hline 우 & 116 & 110 & 172 & 22.81 & 12.50 & $1: 5.1$ \\
\hline $0^{7}$ & 116 & 140 & 177 & 23.21 & 12.60 & $1: 5.2$ \\
\hline $0^{x}$ & 89 & 144 & 176 & 21.90 & 12.90 & $1: 3.9$ \\
\hline q & 136 & 148 & 182 & 25.80 & 13.79 & $1: 5.5$ \\
\hline 우 & 123 & 176 & 087 & 24.21 & 13.14 & $1.5: 2$ \\
\hline $0^{x}$ & 136 & 179 & 188 & 24.80 & 12.79 & $1: 6.3$ \\
\hline 9 & 154 & 188 & 189 & 26.00 & 13.45 & $1: 6.2$ \\
\hline 우 & 103 & 203 & 189 & 24.20 & 13.25 & $1: 5.1$ \\
\hline o & 131 & 205 & 192 & 26.00 & 13.50 & $1: 6.1$ \\
\hline $0^{\pi}$ & 123 & 206 & 193 & 24.70 & 13.12 & $1: 5.2$ \\
\hline $0^{7}$ & 103 & 232 & 202 & 24.60 & 14.05 & $1: 4.0$ \\
\hline 8 & 154 & 351 & 212 & 27.21 & 15.21 & $1: 4.7$ \\
\hline $0^{7}$ & 131 & 310 & 220 & 28.80 & 14.00 & $1: 7.7$ \\
\hline
\end{tabular}

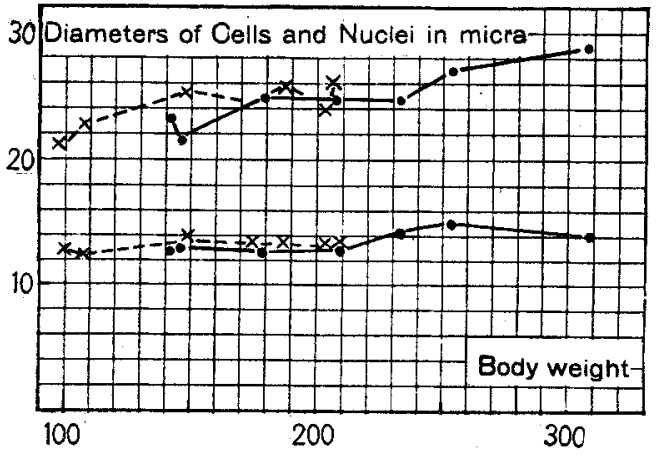

Chart 6 Based on table 11 and giving the computed diameters of the cells and their nuclei, according to sex, on body weight (inbred Albinos).

Male 
As shown in table 10, the female is smaller in size than the male at each age, the female at equal body weight must therefore be older, consequently the cells might have a slightly larger diameter as the result of age, but the difference is small. It would be fair to say, therefore, that the cells, as well as the nuclei, as shown in chart 6 , do indicate a sex difference although it is slight.

This result supports in principle the earlier findings on the standards rats.

TABLE 12

To illustrate the way in which the 'inbred' differ from the 'standard' albino rats in respect of the diameters of the largest cervical sympathetic cells and their nuclei. Data from tables 1 and 11

\begin{tabular}{|c|c|c|c|c|}
\hline \multirow{2}{*}{$\mathbf{A G E}$} & \multirow{2}{*}{ BODY WEIGHT } & \multicolumn{2}{|c|}{ DIAMETERS } & \\
\hline & & Cells & Nucleus & \\
\hline $\begin{array}{r}89 \\
124\end{array}$ & $\begin{array}{l}122^{*} \\
129\end{array}$ & $\begin{array}{l}\mu \\
21.75 \\
28.80\end{array}$ & $\begin{array}{c}\mu \\
12.95 \\
13.40\end{array}$ & $\begin{array}{l}\text { Inbred albino rat } \\
\text { Stock albino rat }\end{array}$ \\
\hline Difference & ge $\ldots \ldots$ & $\begin{array}{l}-7.05 \\
-32.0\end{array}$ & $\begin{array}{l}-0.45 \\
-4.0\end{array}$ & \\
\hline $\begin{array}{l}123 \\
171\end{array}$ & $\begin{array}{l}191 \\
161\end{array}$ & $\begin{array}{l}24.45 \\
28.90\end{array}$ & $\begin{array}{l}13.13 \\
13.00\end{array}$ & $\begin{array}{l}\text { Inbred albino ra } \\
\text { Stock albino rat }\end{array}$ \\
\hline Difference & $\begin{array}{l}\text { e.... } \\
\text { age.. }\end{array}$ & $\begin{array}{l}-4.45 \\
-19.0\end{array}$ & $\begin{array}{l}+0.13 \\
+1.0\end{array}$ & \\
\hline
\end{tabular}

* The values given are the average for the male and female in each instance.

In table 12 is given a comparison of the diameters of the cells and nuclei of the inbred Albino with those of the stock albino rat. The data for the latter have been selected from tables 2 and 11. The sexes are combined.

According to table 12, the inbred has its largest cells in the superior cervical sympathetic ganglion decidedly smaller than those in the stock albino rat of approximately the same body weight. The nucleus, however, shows only a little difference between the two forms, though this difference is in the same direction. 
In her studies on inbreeding, King ('18) states that the closest form of inbreeding, continued for many generations, has not caused a diminution in the average body weight of the inbred rat at any age, and that through the selection of the largest and most vigorous animals for mating, inbred rats are superior in body size to the stock animals reared under similar environmental conditions. Nevertheless, our data as they stand indicate that in the inbred rats the largest cells in this ganglion are clearly smaller in size than in the standard strain. It seems best not to comment on this relation until studies have been made on the wild Norway, and these I hope soon to undertake.

\section{SUMMARY}

\section{A. Based on the data for the 'standard' strain}

1. Between birth and maturity the largest cells in the superior cervical sympathetic ganglion increase about 55 per cent in diameter, while the increase in the nuclei is less than half of this amount.

2. The growth occurs in two phases: the first phase of rapid growth ends at about twenty-five days and the second phase of less rapid growth continues to the end of the record. The present data do not show a marked alteration in rate at puberty.

3. The size of these cells is more closely related to the body weight than to the age of the rat, but there is a marked tendency after puberty for the females to have slightly larger cells than the males of the same age.

4. The nucleus-plasma ratio increases from 1 to 4 at birth to about 1 to 12 at maturity.

5. At maturity the large cells may be classified in three groups: 1) those with Nissl bodies accumulated at the periphery of the cell; 2) those with large masses of Nissl bodies accumulated around the nucleus; 3) those with larger Nissl bodies mingled with small ones, and more or less evenly distributed within the cell. Moreover, a few binuclear cells are found, and in the older rats some pigmented cells are present. 
6. Taking the ganglion as a whole, the large or advanced cells may be present, though in very small numbers, even at birth. This number is slowly increased up to about the fifteenth day, after which the increase is more rapid. Correlated with this is a decrease in the number of small cells which are transformed into the large cells. This transformation continues during the first year and probably throughout life. It appears to occur slightly earlier in the female.

\section{B. Based on the data for the 'inbred' strain}

7. The inbred rats ranged from 89 to 154 days in age. When the values for the diameters of the cells and of the nuclei were plotted on age, these values were greater for the males. The males were also consistently greater in body weight. When the values were plotted on body weight, the values for the females were in general above those for the males. In this case the females were older than the males with which they were compared. It seems probable that at like ages and like body weights, the females would show slightly higher values, but this may be merely an expression of precocity in this growth change in the females.

8. When these cells in the inbred rats are compared with those in the standard animals, table 12, it is seen that while the nuclej differ but little in diameter, the cells in the standard Albinos have a diameter some 25 per cent greater than that found for the inbred cells. It is to be noted that this difference in diameter would make the volume of these cells in the standard Albino about twice that in the inbred, while the nuclei differ but slightly. This difference in the cells is definite, but the significance of it is not discussed here.

9. The ratios of the diameter of the nucleus to that of the cell are in the inbred distinctly less than in the standard Albino: within the same age limits. Compare data in table 1 with those in table 10.

10. The nucleus plasma ratios in the inbred are only about half as great as in the corresponding cells of the standard Albino. Compare data in table 2 with those in table 11. 


\section{LITERATURE CITED}

Apolant, H. 1896 Ueber die sympathischen Ganglienzellen der Nager. Arch. f. mikr. Anat., Bd. 47, S. 461-471.

Carpenter, F. W., And Conel, J. L. 1914 A study of ganglion cells in the sympathetic nervous system, with special reference to intrinsic sensory neurones. Jour. Comp. Neur., vol. 24, pp. 269-279.

Donaldson, H. H. 1915 The rat. Reference tables and data for the albino rat (Mus norvegicus albinus) and the Norway rat (Mus norvegicus). Memoirs of The Wistar Institute of Anatomy and Biology, no. 6. 1917 Growth changes in the mammalian nervous system. The Harvey lectures, series 12, pp. 133-150.

Donaldson, H. H. and Nagasaka, G. 1918 On the increase in the diameters of nerve-cell bodies and of the fibers arising from them--during the later phases of growth (albino rat). Jour. Comp. Neur., vol. 29, pp. 529-552.

Dunn, Elrzabeta H. 1912 The influence of age, sex, weight and relationship upon the number of medullated nerve fibers and on the size of the largest fibers in the ventral root of the second cervical nerve of the albino rat. Jour. Comp. Neur., vol. 22, pp. 131-157.

Gaskell, Walter H. 1920 The involuntary nervous system. Longmans, Green \& Co. New York

Krng, Helen D. 1910 The effects of various fixatives on the brain of the albino rat, with an account of a method of preparing this material for a study of the cells in the cortex. Anat. Rec., vol. 4, pp. 214-244.

1918 Studies on inbreeding. I. The effect of inbreeding on the growth and variability in the body weight of the albino rat. Jour. Exp. Zool., vol. 26, pp. $1-54$.

Kuntz, A. 1910 The development of the sympathetic nervous system in mammale Tour Comn Nonr wal on nn 919_onn 
PLATE 


\section{PLATE 1}

\section{EXPLANATION OF FIGURES}

Cells from the superior cervical sympathetic ganglion of the albino rat. Figures 1 to 7 magnified in plate by 2000 .

1 An advanced cell and several young cells; male, one day old.

2 An advanced cell with Nissl bodies evenly distributed; male, five days old.

3 A cell with Nissl bodies accumulated at the periphery, common between twenty days and sixty days; female, twenty days.

4 A cell with Nissl bodies accumulated around the nucleus, common between twenty days and sixty days and also found at later ages; male, sixty days old.

5 A cell with larger Nissl bodies more or less evenly distributed common after one hundred days; female, 124 days old.

6 A binuclear cell; female, one day old.

7 A binuclear cell; male, one year old. 

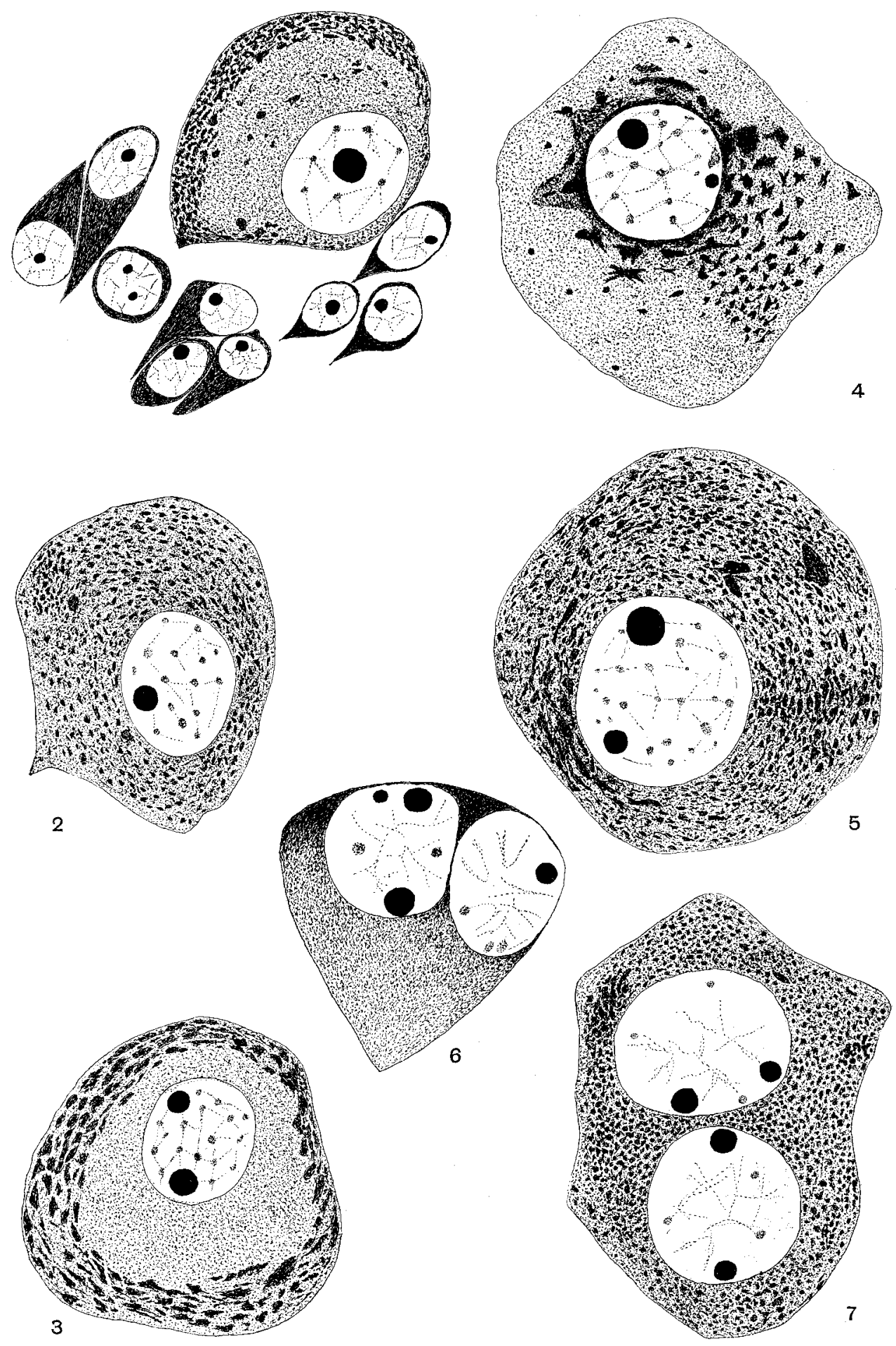